\title{
Environmental Behavior and Fate of Methyl tert-Butyl Ether (MTBE)
}

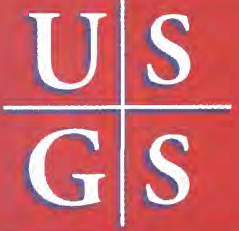

\section{By Paul J. Squillace, James F. Pankow, Nic E. Korte, and John S. Zogorski}

\section{Abstract}

When gasoline that has been oxygenated with methyl tert-butyl ether (MTBE) comes in contact with water, large amounts of $M T B E$ can dissolve; at 25 degrees Celsius the water solubility of MTBE is about 5,000 milligrams per liter for a gasoline that is 10 percent MTBE by weight. In contrast, for a nonoxygenated gasoline, the total hydrocarbon solubility in water is typically about 120 milligrams per liter. MTBE sorbs only weakly to soil and aquifer materials; therefore, sorption will not significantly retard MTBEs transport by ground water. In addition, $M T B E$ generally resists degradation in ground water. The half-life of MTBE in the atmosphere can be as short as 3 days in a regional airshed. MTBE in the air tends to partition into atmospheric water, including precipitation. However, washout of gas-phase MTBE by precipitation would not, by itself, greatly alter the gas-phase concentration of the compound in the air. The partitioning of $M T B E$ to precipitation is nevertheless strong enough to allow for up to 3 micrograms per liter or more inputs of MTBE to surface and ground water.

\section{Introduction}

Fuel oxygenates are voluntarily added to gasoline to enhance the octane of gasoline in many areas of the United States, and fuel oxygenates have been used since 1988 to improve air quality (Begley and Rotman, 1993) in some metropolitan areas. However, since November 1, 1992 , the 1990 Clean Air Act Amendments require areas that exceed the national ambient air-quality standard for carbon monoxide (carbon monoxide nonattainment areas) to use oxygenated gasoline during the winter when the concentrations of carbon monoxide are highest.

Furthermore, since January 1995, the 1990 Clean Air Act Amendments also require nine metropolitan areas that have the most severe ozone pollution to use, year-round, reformulated gasoline that contains fuel oxygenates. Numerous additional metropolitan areas have chosen to participate in the oxygenated fuels and reformulated gasoline programs.

Currently, oxygenates are added to more than 30 percent of the gasoline used in the United States (U.S. Environmental Protection Agency, 1994) and the percentage may increase in the future. Indeed, it has been projected that by the year 2000 fuel oxygenates will be added to 70 percent of the gasoline used in the United States (Shelly and Fouhy, 1994). Because of its low cost, ease of production, and favorable transfer and blending characteristics, methyl tert-butyl ether (MTBE) is the most commonly used fuel oxygenate (Ainsworth, 1992; Shelly and Fouhy, 1994). It can be produced at the refinery, it blends easily without separating from gasoline, and the MTBE gasoline blend can be transferred through existing pipelines. In the United States, almost all MTBE is used in gasoline. The second most-used fuel oxygenate is ethanol. Other oxygenates in limited commercial use include methanol, ethyl tert-butyl ether, tert-amyl methyl ether, and diisopropyl ether (Zogorski and others, 1996).

The U.S. Environmental Protection Agency has tentatively classified MTBE as a possible human carcinogen, but no drinking-water regulation has been established for MTBE (U.S. Environmental Protection Agency, 1996). The U.S. Environmental Protection Agency, however, has issued a draft lifetime health advisory of 20 to 200 $\mu \mathrm{g} / \mathrm{L}$ (micrograms per liter); this health advisory is the maximum concentration in drinking water that is not expected to cause any adverse noncarcinogenic effects over a lifetime of exposure with a specified margin of safety.

MTBE has been detected in ground water (Squillace and others, 1996) and stormwater (Delzer and others, 1996). Of the 60 volatile organic compounds (VOCs) analyzed in samples of shallow ambient ground water that were collected from eight urban areas during 1993-94 as part of the U.S. Geological Survey's National Water-Quality Assessment program, MTBE was the second most frequently detected compound (after trichloromethane, which is also named chloroform) (Squillace and others, 1996). The ground-water samples were collected 
from 5 drinking-water wells, 12 springs and 193 monitoring wells. At a reporting level of $0.2 \mu \mathrm{g} / \mathrm{L}$, MTBE was detected in water from 27 percent of the 210 wells and springs sampled, but no MTBE was detected in water from the drinking-water wells. Measurable concentrations of MTBE were also found in some of 592 stormwater samples collected by the U.S.

Geological Survey in 16 cities and metropolitan areas required to obtain National Pollutant Discharge Elimination System permits (Delzer and others, 1996). MTBE was the seventh most frequently detected VOC, occurring in 6.9 percent of the stormwater samples. MTBE had a higher reporting level of $1.0 \mu \mathrm{g} / \mathrm{L}$ for most of the stormwater samples, and it is likely that this resulted in fewer detections when compared to some of the other VOCs that had a reporting level of $0.2 \mu \mathrm{g} / \mathrm{L}$ for all of the samples. Where MTBE was detected, concentrations ranged from 0.2 to 8.7 $\mu \mathrm{g} / \mathrm{L}$. Eighty-three percent of all stormwater samples that had detectable concentrations of MTBE were collected between October 1 and March 31. This period of time is approximately when oxygenated gasoline is used in carbon monoxide nonattainment areas.

The purpose of this document is to answer commonly asked questions relating to the environmental behavior and fate of MTBE. Where appropriate, this report contrasts the properties of MTBE with those of benzene, methylbenzene (also named toluene), ethylbenzene, and xylenes (BTEX) compounds. BTEX compounds are present in all gasoline and are the most soluble and toxic compounds associated with nonoxygenated gasoline.

\section{How, and to what extent, does MTBE partition to air, water, and subsurface solids?}

Volatilization and condensation are the complementary processes that allow the exchange of MTBE across an air-water interface. In this context, volatilization refers to the movement of MTBE from water into the atmosphere, whereas condensation refers to the movement of MTBE from the atmosphere into water. Both processes are driven by concentration gradients between the air and water phases.

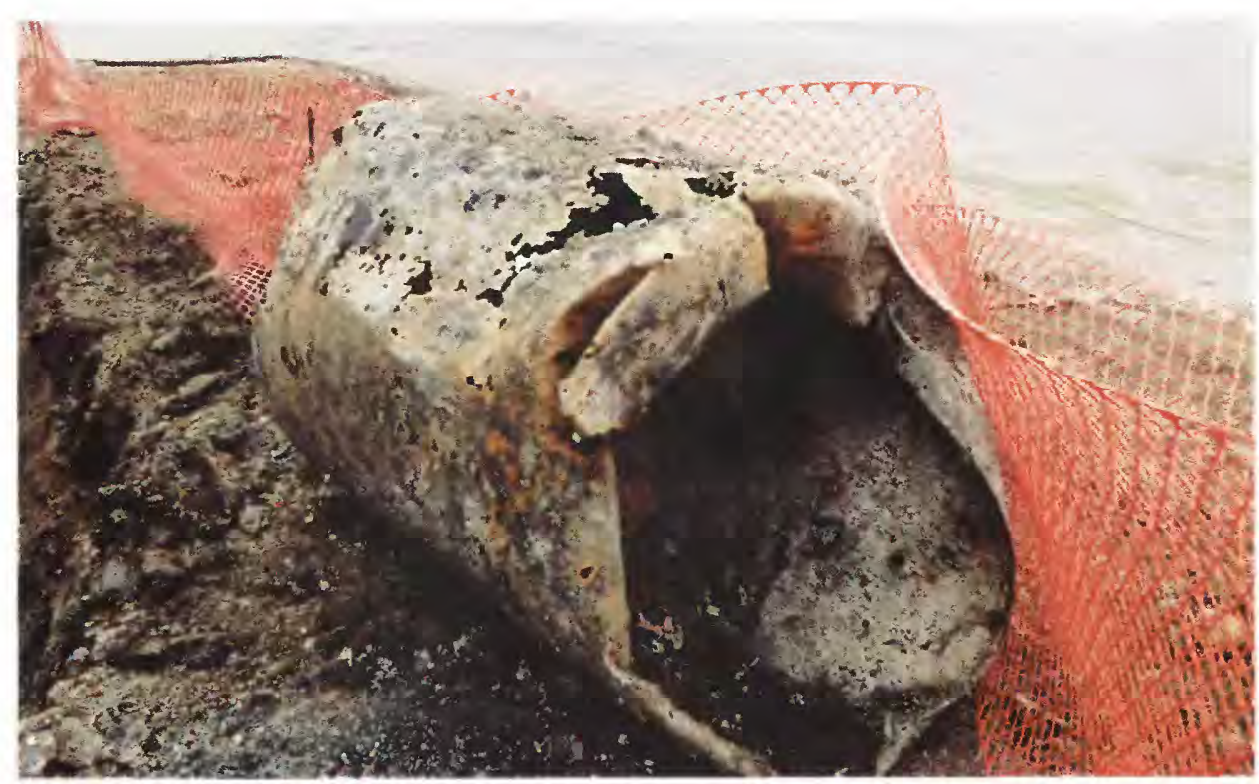

Excavated storage tank showing severe corrosion.

When compared to benzene, MTBE tends to partition strongly from the gas phase into the water phase if contaminated air is brought into contact with uncontaminated water. Given sufficient time, equilibrium can be established between concentrations of MTBE in air and water as described by Henry's Law constant, which is temperature dependent. If the same units are selected for the air and water concentrations, then Henry's Law constant is dimensionless. The value of the dimensionless Henry's law constant for MTBE is 0.022 at 25 degrees Celsius $\left({ }^{\circ} \mathrm{C}\right)$ (Robbins and others, 1993); a compound with a value of 0.05 or larger would be very volatile from water.

Consequently, MTBE tends to stay in the water phase, which explains why MTBE is somewhat difficult to remove from water by aeration. In contrast, the dimensionless Henry's Law constant for benzene is 0.22 at $25^{\circ} \mathrm{C}$ (Howard and others, 1990), which indicates that it volatilizes from water and can be removed by aeration. However, the Henry's Law constant alone cannot be used to predict the volatility of MTBE from natural water because volatilization also depends on environmental variables such as surface-water turbulence, and to some extent wind velocity.

Water solubility is probably the most important chemical property affecting the partitioning of organic compounds between water and subsurface solids. Many organic compounds exhibit water solubilities in the low milligrams-per-liter to micrograms-per-liter range. In general, these low solubilities indicate a strong partitioning to the organic carbon associated with the subsurface solids. However, MTBE is very water soluble compared to the BTEX compounds and other components in gasoline; the solubility of pure liquid MTBE in water is about 50,000 $\mathrm{mg} / \mathrm{L}$ (milligrams per liter) whereas the next most-soluble component of gasoline is benzene, which has a solubility of 1,780 mg/L (Mackay and orhers, 1992, 1993).

\section{What are the potential sources of MTBE and their effect on surface water and ground water?}

There are point and nonpoint sources of MTBE affecting surface- and groundwater quality. The concentrations of MTBE in water associated with pointsource spills can be very large. Gasoline spills to the land surface and releases from above-ground and underground storage tanks are examples of point sources of contamination. As indicated previously, at ambient temperatures the solubility of pure MTBE in water is about $50,000 \mathrm{mg} / \mathrm{L}$ (Mackay, and others, 1993). However, the solubility of MTBE in water is reduced when other organic compounds are present because MTBE partitions between the organic mixture and water; a gasoline that is 10 percent by weight MTBE, reduces the solubility of MTBE in water to about $5,000 \mathrm{mg} / \mathrm{L}$ at room temperature $\left(25^{\circ} \mathrm{C}\right)$ (Barker and others, 1991; Zogorski and others, 1996). In contrast, for a 
nonoxygenated gasoline, the total

hydrocarbon solubility in water is typically about $120 \mathrm{mg} / \mathrm{L}$ (Poulsen and others, 1992). The high solubility of MTBE in water combined with its high concentrations in an oxygenated gasoline can result in high concentrations of MTBE in surface water and ground water contaminated by point sources of oxygenated gasoline. However, lower concentrations also can result with time if MTBE in the gasoline has been depleted by the dissolution process and the dilution of contaminated water by uncontaminated water.

Precipitation can be a nonpoint source of MTBE to surface and ground water; moreover, once MTBE is in water it is expected to move between surface and ground water with the natural movement of water. Local gas-phase concentrations of MTBE can be used to predict the concentrations of MTBE in the local precipitation. The amount of MTBE removed from the air by precipitation will not significantly reduce the gas-phase concentration of MTBE in the air; $2.5 \mathrm{~cm}$ of precipitation will remove less than 0.5 percent of the MTBE in the air at a temperature of $20^{\circ} \mathrm{C}$ (Zogorski and others, 1996). Even though little net loss occurs from atmospheric washout, the loss may nevertheless be important as a nonpoint source of MTBE to water. Although concentrations of
MTBE in the air are not frequently measured, concentrations in urban air appear to be on the order of 1 part per billion by volume (ppb-v), or less (Zogorski and others, 1996). The corresponding equilibrium concentration in precipitation at a winter temperature of $5{ }^{\circ} \mathrm{C}$ would be $1 \mu \mathrm{g} / \mathrm{L}$ or less. Given higher concentrations such as 3 ppb-v, the equilibrium concentrations in water would be about $3 \mu \mathrm{g} / \mathrm{L}$ (Squillace and others, 1996). Given even higher air concentrations such as 30 ppb-v, the equilibrium concentrations in water would be about $30 \mu \mathrm{g} / \mathrm{L}$. Elevated concentrations of MTBE in the air immediately surrounding local sources (for example, highways, gasoline stations, parking garages, or refineries) would result in increased concentrations in local precipitation when averaged over months to years.

\section{Can the source of MTBE be determined from the concentrations of MTBE and BTEX compounds detected in surface water or ground water?}

The concentrations of MTBE and BTEX compounds can lead one to suspect point or nonpoint sources of contamination. Where high concentrations of MTBE and BTEX compounds (greater than 30 $\mu \mathrm{g} / \mathrm{L}$ ) are detected in ground water, the source of contamination is probably a point source, such as a leaking underground storage tank. The concentrations of MTBE from a point source can be high. For example, MTBE concentrations as large as $200 \mathrm{mg} / \mathrm{L}$ have been measured in ground water near a point-source spill of gasoline (Garrett and others, 1986).

When small concentrations $(0.2$ to 3 $\mu \mathrm{g} / \mathrm{L}$ ) of MTBE are detected in ground water, the source of contamination may be a point source but more likely is a nonpoint source such as atmospheric washout. MTBE plumes originating from pointsource gasoline releases generally occupy a larger volume of the subsurface compared to BTEX compounds, and concentrations of MTBE at the leading edge of a contaminant plume are low but usually increase with time. Therefore, if small concentrations of MTBE were detected in samples at a location contaminated by a point source, then generally one would expect the concentrations of MTBE and detections of BTEX compounds to increase with time at the same location.

Atmospheric washout and water interaction with contaminated road surfaces are possible nonpoint sources of MTBE to surface water, but the concentrations associated with these sources are generally small. As indicated previously, concentrations of MTBE and BTEX were measured

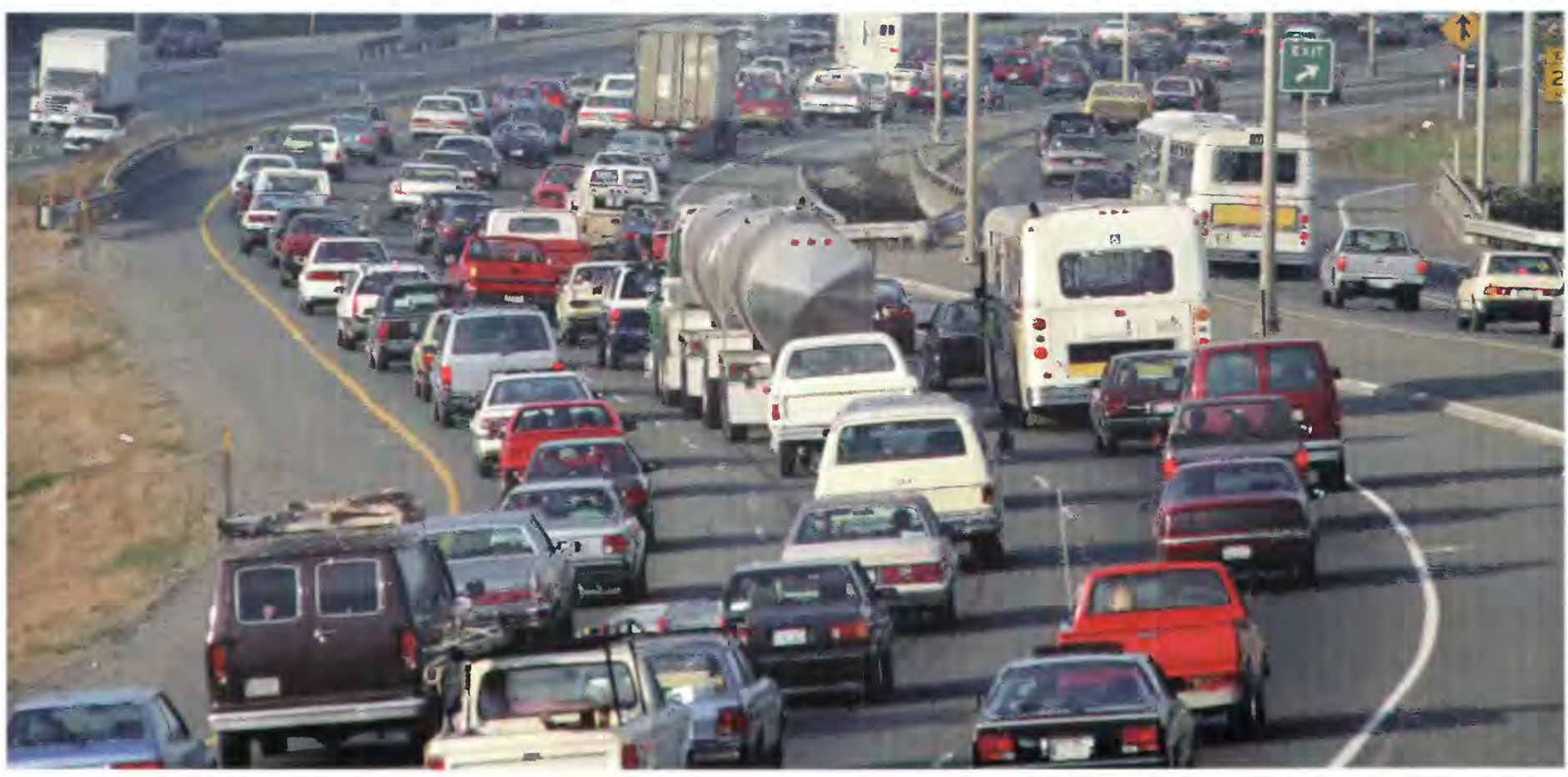


in 592 stormwater samples collected by the U.S. Geological Survey in 16 cities and metropolitan areas required to obtain National Pollutant Discharge Elimination System permits (Delzer and others, 1996). The highest concentration of MTBE was less than $10 \mu \mathrm{g} / \mathrm{L}$ and the sum of BTEX concentrations in each stormwater sample was less than $20 \mu \mathrm{g} / \mathrm{L}$.

\section{What natural processes degrade MTBE and how quickly does degradation occur?}

Degradation of an organic compound refers to its transformation by abiotic or biotic reactions. The degradation of organic compounds normally leads to the formation of other organic compounds. The ultimate mineralization (complete breakdown) of an organic compound to carbon dioxide and water can involve many reactions and a long period of time. MTBE can degrade in the atmosphere by various processes including photolysis and reactions with the hydroxyl radical, ozone, and nitrate radicals; recent research indicates that MTBE reaction with the hydroxyl radical is the most prevalent (Smith and others, 1991; Wallington and others, 1988). Biological transformations often provide the predominant decay pathways in water and soil, and the complete mineralization of an organic molecule in water and soil is almost always a consequence of microbial activity (Alexander, 1981; Schnoor and others, 1987).

Estimates of the atmospheric half-life (time required for one half of the amount of the compound to degrade) of MTBE can be as short as 3 days in a regional airshed (Smith and others, 1991; Wallington and others, 1988; Zogorski and others, 1996). This estimated half-life assumes a hydroxyl radical concentration of $10^{6}$ radicals $/ \mathrm{cm}^{3}$ in the regional airshed. However, concentrations of hydroxyl radical could be lower in air near metropolitan areas and therefore MTBE could resist degradation until advection carries MTBE outside the metropolitan area. The major degradation product of MTBE in the atmosphere is tert-butyl formate. Other degradation products include methyl acetate (acetic acid), acetone, tert-butyl alcohol, and formaldehyde (Howard and others, 1996).
In water, BTEX compounds undergo biological transformations; however, most studies have indicated that MTBE does not biodegrade easily under various environmental conditions. If a research investigation determines that a compound does not degrade, a half-life is not reported and the compound is simply classified as recalcitrant. MTBE is generally reported as recalcitrant and there

\section{How far can MTBE travel in streams and rivers before it volatilizes?}

Although MTBE can volatilize from water, half-lives in rivers and streams can be greater than 1 day, and travel distances range from about $0.8 \mathrm{~km}$ for shallow streams to more than $900 \mathrm{~km}$ for deep rivers before half of the MTBE is volatilized (Pankow and others, 1996).

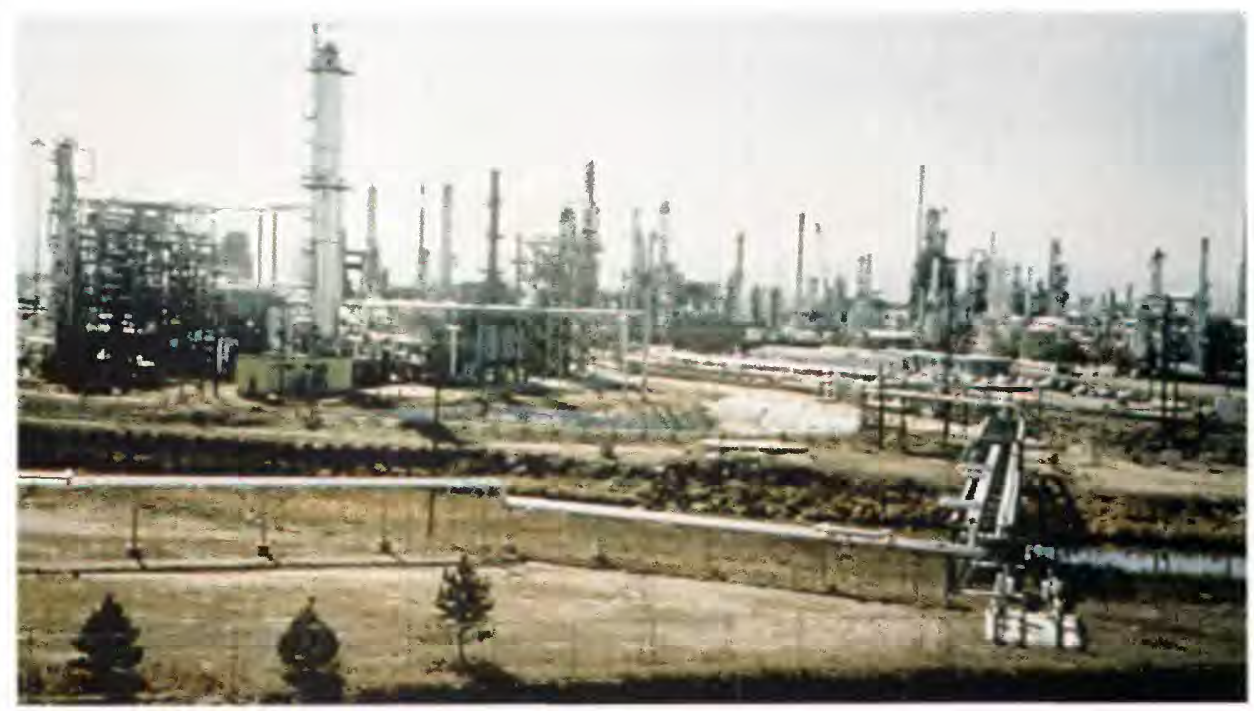

Petroleum refinery

are no widely accepted estimates of the half-life. Investigators have reported that MTBE is recalcitrant in anaerobic laboratory studies including denitrifying conditions, sulfate-reducing conditions, methanogenic-reducing conditions, and anaerobic conditions in landfill-affected aquifer material, soils, and sludges (Fujiwara and others; 1984; Jensen and Arvin, 1990; Yeh and Novak, 1991, 1994; Suflita and Mormile, 1993; Mormile and others, 1994). Yeh and Novak (1995) also reported that there was no degradation of MTBE in an aerobic laboratory study after more than 100 days of incubation. Nevertheless, degradation of MTBE has been reported on occasion and this indicates that some microorganisms are able to degrade MTBE (Thomas and others, 1988; Daniel, 1995). The degradation of MTBE in ground water can lead to the formation of tert-butyl alcohol, which has been determined to be a carcinogen in laboratory animals (Cirvello and others, 1995).
Ice on rivers and streams will stop all volatilization of MTBE from the water. Factors that affect the volatilization rate of MTBE in surface water include water velocity, water depth, water temperature, wind speed, and air temperature; in many cases, MTBE volatilizes at rates that are most dependent on the depth and velocity of the flow. No single volatilization rate characterizes the loss process from streams and rivers. In deep and slow moving flows, MTBE volatilizes at rates similar to those for the BTEX compounds. In shallow and fast moving flows, MTBE volatilizes at rates that are significantly slower than those for BTEX compounds (Pankow and others, 1996).

\section{How quickly can MTBE enter ground water and how fast can it travel?}

Because MTBE tends to stay in the water and not sorb to subsurface solids, it can move to the ground water at almost the same velocity as the recharge water. The downward velocity and travel times of 
recharge water to the water table is extremely variable throughout the United States and depends on many factors, such as precipitation, evapotranspiration, hydraulic conductivity of the materials in the unsaturated zone, and the thickness of the unsaturated zone. In some areas of the United States, where the depth to water is less than $3 \mathrm{~m}$ and the unsaturated zone is permeable, recharge from precipitation can reach the underlying aquifer in a few days or less. In other areas, precipitation falling on the land surface may never reach the underlying aquifer; however, installation of retention ponds and recharge wells for stormwater runoff will increase the rate of ground-water recharge.

Once MTBE is in the ground water, it can move at virtually the same velocity as the water, which is one reason why MTBE plumes generally occupy a large portion of the subsurface compared to BTEX compounds. The ratio of the ground-water velocity to the velocity at which a compound is transported is frequently referred to as the retardation factor, $\mathrm{R}$. The actual values of $\mathrm{R}$ for a particular compound depend on aquifer properties, such as porosity and organic carbon content. A compound that moves at one-half the velocity of the ground water has an $R$ value of 2. For MTBE, $\mathrm{R}$ is fairly close to 1 for typical aquifers whereas the BTEX compounds have $R$ values that can range from 1.1 to about 2.0 (Zogorski and others, 1996); physical and chemical characteristics indicate that compound mobilities generally increase in the following order: xylene, ethylbenzene, toluene, benzene, MTBE (Odermatt, 1994).

Ground-water velocities are extremely variable and depend on the permeability, porosity, and hydraulic gradient of the aquifer. Velocities under typical hydraulic gradients can range from a few millimeters per year to a meter per day. Ground-water velocities near a pumping well can be even larger due to the large hydraulic gradients that can exist near these wells.

\section{Are there environmental processes that will concentrate MTBE in water or air?}

At this time, there are no known environmental processes that will concentrate MTBE within water or air; however, MTBE will move between air and water until equilibrium is established. Therefore the concentrations of MTBE in air or water can change with time until equilibrium is established. Furthermore, increased use of MTBE can upset established equilibrium by changing the atmospheric concentrations of MTBE; in general, those metropolitan areas where MTBE is used only as an octane enhancer will probably have lower atmospheric concentrations of MTBE than metropolitan areas where MTBE is added to all gasoline sold to meet the requirements of the 1990 Clean Air Act Amendments.

\section{Do other alkyl ether oxygenates behave similarly to MTBE?}

There is limited information on the behavior and fate of other alkyl ether oxygenates. However, available chemicalproperty data indicate that the solubilities of the other ethers are also high. Therefore, the subsurface retardation factors should be similar to MTBE in a given circumstance. Volatilization rates from water are expected to be similar to MTBE. All these factors indicate that other alkyl ether oxygenates should partition between air, water, and soil similar to MTBE. The expected half-lives of these compounds in air are also similar to MTBE, and their biodegradation is similarly limited (Zogorski and others, 1996).

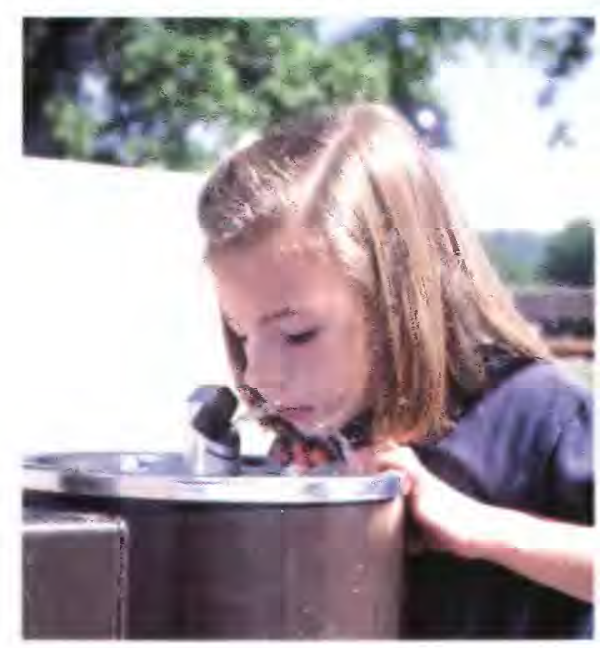

\section{How easily can MTBE be removed from a drinking water supply?}

MTBE's high water solubility and resistance to biodegradation complicates its removal from water. There have been several evaluations of remedial technologies for MTBE, but these have generally indicated low efficiency and high costs for the technologies. For example, Garrett and others (1986) concluded that filtration of MTBE-contaminated ground water through activated carbon was not costeffective; a 0.06- $\mathrm{m}^{3}$ (cubic meter) bed of activated carbon lasts only a month or less on a household treatment system that has an influent concentration of MTBE of only a few milligrams per liter. In other studies, MTBE-contaminated water was remediated, and air stripping with or without carbon adsorption had the lowest treatment costs (International Technology Corporation, 1991; Truong and Parmele, 1992). A recent survey of 15 air-stripping installations indicated that 56 to 99.9 percent of the MTBE was removed; the median removal rate was 91 percent (Groundwater Technology Inc., 1990). Because of the relatively low efficiency of air stripping for MTBE, increasing the Henry's Law constant by heating the process water may be a cost-effective approach (Butillo and others, 1994). Regarding the removal of MTBE from water, heating the air-stripper influent stream to $27^{\circ} \mathrm{C}$ over a $9 \mathrm{~m}$ column packed with activated carbon was equivalent to using $10^{\circ} \mathrm{C}$ water and a $18 \mathrm{~m}$ column packed with activated carbon. When there can be no air emissions, use of oxidation with ultraviolet light/peroxide/ozone also is a feasible water-treatment alternative. This approach, however, has high capital and operating costs relative to other treatments (Zogorski and others, 1996).

Hydrogen peroxide, provided initially as a source of oxygen to support microbial degradation, has been found to hydrolyze MTBE with the immediate formation of tert-butyl alcohol and some acetone (Yeh and Novak, 1995). The reaction occurred only when iron was added to act as a catalyst for the release of hydroxyl radicals from the hydrogen peroxide. This reaction, however, does not have wide applicability because it is inefficient in aerobic environments or in near-neutral $(\mathrm{pH}$ greater than 6.5 standard units) to alkaline environments.

Despite the resistance of MTBE to indigenous bacteria, biotreatment methods might be developed. Recent research has demonstrated that bacterial populations and certain pure bacterial strains, when isolated from biotreated sludges and other sources, have the ability to use MTBE as a sole carbon source (Salanitro and others, 1994; Mo and others, 1995). 


\section{References Cired}

Ainsworth, S., 1992, Oxygenates seen as hot market by industry: Chemical Engineering News, v. 70, p. 26-30. Alexander, Martin, 1981, Biodegradation of chemicals of environmental concern: Science, v. 211, no. 9, p. 132-138.

Barker, J.F, Gillham, R.W., Lemon, L., Mayfield, C.I., Poulsen, M., and Sudicky, E.A., 1991, Chemical fate and impact of oxygenates in groundwater-Solubility of BTEX from gasoline-Oxygenate Compounds: Washington, D.C., American Petroleum Institute Publication 4531, 90 p.

Begley, Ronald, and Rotman, David, 1993, Health complaints fuel federal concern over MTBE: Chemical

Week, v. 152 , no. 10 , p. 7.

Butillo, J.V., Pulido, A.D., Reese, N.M., and Lowe, M.A., 1994, Removal efficiency of MTBE in waterConfirmation of a predictive model through applied technology, in Proceedings of the Petroleum Hydrocarbons and Organic Chemicals in Ground Water section of the Prevention, Detection, and Remediation Conference, Houston, Texas, November 2-4, 1994: Dublin, Ohio, National Ground Water Association, p. 91-105.

Cirvello, J.D., Radovsky, Ann, Heath, J. E., Farnell, D.R., and Lindamood, Charles, 1995, Toxicity and carcinogenicity of $\mathrm{t}$-butyl alcohol in rats and mice following chronic exposure in drinking water: Toxicology and Industrial Health, v. 11, no. 2, p. 151-166.

Daniel, R.A., 1995, Intrinsic bioremediarion of BTEX and MTBE - Field, laboratory and computer modeling studies: Raleigh, North Carolina State University, Department of Engineering, Masters Thesis, 325 p.

Delzer, G.C., Zogorski, J.S., Lopes, T.J., and Bosshart, R.L., 1996, Occurrence of the gasoline oxygenate MTBE and BTEX compounds in urban stormwater in the United States, 1991-95: U.S. Geological Survey Water Resources Investigations Report 96-96-4145, 6 p.

Fujiwara, Yasuo., Kinoshita, Tatsuo., Sato, Hiroshi, and Kojima, Ichiro., 1984. Biodegradation and bioconcentration of alkylethers: Yukaguku, v. 33, p. 111-114.

Garrett, Peter., Moreau, Marcel, and Lowry, J.D., 1986, MTBE as a ground water contaminant: in Proceedings of the 1986 National Water Well Association and American Petroleum Institute Conference on Petroleum and Organic Chemicals in Ground Water, Houston, Texas: Dublin Ohio, National Water Well Association, p. 227-238.

Groundwater Technology Inc., 1990, A compilation of field-collected cost and treatment effectiveness data for the removal of dissolved gasoline components from groundwater, November 1990: Washington, D.C., American Petroleum Publication no. 4525, 240 p.

Howard, P.H., Sage, G.W., Jarvis, W.F., and Gray, D.A, 1990, Handbook of environmental fate and exposure data for organic chemicals-Volume IV: Chelsa, Mich., Lewis Publishers, Inc., 578 p.

Howard, C.J., Russell, Armistead, Atkinson, Roger, Calvert, Jack, 1996, Air quality benefits of the winter oxyfuel program: Washington D.C., Office of Science and Technology Policy, $91 \mathrm{p}$.

International Technology Corporation, 1991, Costeffective, alternative treatment technologies for reducing the concentrations of ethers and alcohols in groundwater: Washington, D.C., American Petroleum Institute Publication no. 4497, 220 p.

Jensen, H.S., and E. Arvin, 1990, Solubility and degradability of the gasoline additive MTBE, methyl-tertbutyl-ether and gasoline compounds in water: in Arendt, F., Hinsenveld, M., and van den Brink, W.J., eds, Contaminated Soil '90: Dordrecht, The Netherlands, Kluwer Academic Publishers, p. Ix11445-448.
Mackay, Donald, Shiu, G.W.Y., and Ma, K.C., 1992, Illustrated handbook of physical-chemical properties and environmental fate for organic chemicalsMonoaromatic hydrocarbons, chlorobenzenes, and PCBsVolume I: Chelsea, Mich., Lewis Publishers, 697 p. 1993, Illustrated handbook of physical-chemical properties and environmental fate for organic chemicals-volatile organic chemicals-Volume III: Chelsea, Michigan., Lewis Publishers Inc, 916 p.

Mo, K. Lora, C.O., Wanken, A., and Kulpa, C.F., 1995, Biodegradation of methyl-t-butyl ether by pure bacterial cultures: American Society of Microbiology, 95th General Meeting, Washington, D.C., May 8-12, p. 408.

Jensen, H.M., and Arvin, Erik., 1990, Solubility and degradability of the gasoline additive MTBE, methyl-tertbutyl-ether and gasoline compounds in water, in Arendt, F., Hinsenveld, M., and van den Brink, W.J., eds. Contaminated Soil '90: Dordrecht, The Netherlands, Kluwer Academic Publishers, p. 445-448.

Mormile, M. R., Liu, Shi, and Suflita, J. M., 1994, Anaerobic biodegradation of gasoline oxygenates: extrapolation of information to multiple sites and redox conditions: Environmental Science and Technology, v. 28, p. $1727-1732$.

Odermatt, J. R., 1994, Natural chromatographic separation of benzene, toluene, ethylbenzene, and xylenes (BTEX compounds) in a gasoline contaminated ground water aquifer: Organic Chemistry, v. 21, no. 10/11, p. 1141-1150.

Pankow, J.F, Rathbun, R.E., and Zogorski, J.S., 1996, Calculated volatilization rates of fuel oxygenate compounds and orher gasoline-related compounds from rivers and streams: Chemosphere, v.33, no.5, p.921-937.

Poulsen, Mette, Lemon, Lloyd, and Barker, J.F., 1992, Dissolution of monoaromatic hydrocarbons into groundwater from gasoline-oxygenate mixtures: Environmental Science \& Technology, v. 26, no. 12, p. 2483-2489.

Robbins, G.S., Wang, Suya., and Stuart, J.D., 1993, Using the static headspace method to determine Henry's Law constants: Analytical Chemistry, v. 65, no. 21, p. 3113-3118.

Salanitro, J.P., Diaz, L.A., Williams, M.P., and Wisniewski. H.L., 1994, Isolation of a bacterial culture that degrades methyl t-butyl ether: Applied and Environmental Microbiology, v. 60, no. 7, p. 2593-2596.

Schnoor, J.L. Sato, Chikashi, Mckechnie, Deborah, Dipak Sahoo, 1987, Processes, coefficients, and models for simulating toxic organics and heavy metals in surface waters: Athens, Georgia, U.S. Environmental Protections Agency, $303 \mathrm{p}$.

Shelly, Suzanne., and Fouhy, Ken, 1994, The drive for cleaner burning fuel: Chemical Engineering, January, p. 61-63.

Smith. D.F., Kleindienst, T.E., Hudgens, E.E., McIver, C.D. and Buffalini, J.J., 1991, The photooxidation of methyl tertiary butyl ether: International Journal of Chemistry Kinetics, v. 23, p. 907-924.

Squillace, P.J., Zogorski, J.S., Wilber, W.G., and Price, C.V., 1996, Preliminary assessment of the occurrence and possible sources of MTBE in groundwater in the United States, 1993-1994: Environmental Science and Technology, v. 30, no. 5, p. 1721-1730.

Suflita, J. M., and Mormile, M. R., 1993, Anaerobic biodegradation of known and potential gasoline oxygenates in the terrestrial subsurface: Environmental Science and Technology, v. 27, p. 976-978.

Thomas, J.M., Clark, G.L., Tomson, M.B., Bedient, P.B., Rifai, H.S., and Ward, C.H., 1988, Environmental fate and attenuation of gasoline components in the subsurface: Washington, D.C., American Petroleum Institute, final report, p. 111.
Truong, K.N., and Parmele, C.S., 1992, Cost-effective alternative treatment technologies for reducing the concentrations of methyl tertiary butyl ether and methanol in groundwater: Hydrocarbon Contaminated Soils and Groundwater, v. 27, no. 2, p. 461-486.

U.S. Environmental Protection Agency, 1994, Health risk perspective on fuel oxygenates: EPA 600/R-94/217, Office of Research and Development, December, $101 \mathrm{p}$.

U.S. Environmental Protection Agency, 1996, Drinking water regulations and health advisories: Washington, D.C., Office of Water, $10 \mathrm{p}$.

Wallington, T.J., Dagaut, Philippe., Liu, Renzhang, and Kurylo, M.J., 1988, Gas-phase reactions of hydroxyl radicals with the fuel additives methyl tert-butyl ether and tert-butyl alcohol over the temperature range $240-440 \mathrm{~K}$ : Environmental Science and Technology, v. 22, p. 842-844.

Yeh, C.K., and J.T. Novak, 1991, Anaerobic biodegradation of oxygenates in the subsurface, in Proceedings of the 1991 Petroleum Hydrocarbons and Organic Chemicals in Ground Water- Prevention, Detection and Restoration, November 20-22, 1991, Housron, Texas: National Water Well Association, Ground Water Management Book 8 of the Series, p. 427-441. 1994, Anaerobic biodegradation of gasoline oxygenates in soils: Water Environment Research, v. 66 , no. 5 , p. $744-752$.

1995, The effect of hydrogen peroxide on the degradation of methyl and ethyl tert-butyl ether in soils: Water Environment Research, v.67, no. 5 , p. $828-834$.

Zogorski, J.S., and others, 1996, Fuel oxygenates and water quality - Current understanding of sources, occurrence in natural water, environmental behavior, fate, and significance: Washington D.C., Office of Science and Technology Policy, 91 p.

\section{Additional information on NAWQA and other U.S. Geological Survey programs can be found by accessing the NAWQA "home page" on the World Wide Web at "http://wwwrvares.er.usgs.gov/ nawqa/naqwa_home.html."}

For more information, contact:

Paul Squillace

U.S. Geological Survey

1608 Mountain View Rd.

Rapid City, SD 57702

(605) 394-1780 (ext. 239)

pjsquill@usgs.gov 